\title{
Filamentous Algae of a Hill Stream Of Kerala, India
}

\author{
Smitha Sebastian ${ }^{1}$, Ammini Joseph ${ }^{2}$ \\ ${ }^{1 \& 2}$ School of Environmental Studies, Cochin University of Science and Technology, Kerala, India
}

\begin{abstract}
The diversity of filamentous algal flora of a minor stream of Thodupuzha river, Kerala was studied. During the study period thirteen freshwater algal species were observed. They comprised species of Cyanobacteria, Chlorophyta and Charophyta. Presence of certain algae can indicate the pollution status in the stream.
\end{abstract}

Key Words-Stream, Cyanobacteria, Chlorophyta, Charophyta., Filamentous algae

\section{Introduction}

Filamentous algae are important components of the river vegetation of small streams mostly attached to substrates as periphyton or in pools of the stream as metaphyton. Stevenson (1996) has grouped the filamentous benthic algae of river into the taxonomic groups Cyanobacteria, Rhodophyta, Chrysophyta, Xanthophyta, Phaeophyta, Bacillariophyta and Chlorophyta [1]. The functional role of filamentous algae is related to autotrophic production and support of food web (Biggs and Smith, 2002[2]; Januer and Dokulil, 2006[3]; Shields et al., 2008[4] ). The stream algae also influence the oxygen budget as well as the nutrient cycling (Munn and Tesoriero, 2010[5]; Wetzel, 2001[6]; Ziglio et al., 2006[7]).

The biomass of periphyton is related to the characteristics of the flowing water. The structure and dynamics of the periphyton communities have been used to classify waterways (Denicola et al., 2004[8]; Wargo and Holt, 2004[9]). Generally warmer temperature, high nutrient load and reduced flows support their luxuriant growth (Baba et al., 2011[10]; Cascallar et al., 2003[11]; Giorgi and Malacalza, 2002[12]). Their proliferation negatively impact macro invertebrate abundance and consequently the food web (Biggs, 2000[13]; Dangles and Guerold, 1999[14]). The capacity of certain species to tolerate high nutrient state has led to their application in waste water treatment (Abdel-Raouf et al., 2012[15]; Marinelarena and Giorgi, 2001[16]).Moreover in the commercial production of microalgae the filamentous forms are the better biomass producers and more economical to harvest (Christenson and Sims, 2011[17]; Khanal et al., 2010[18]; Markou and Georgakakis, 2011[19]).

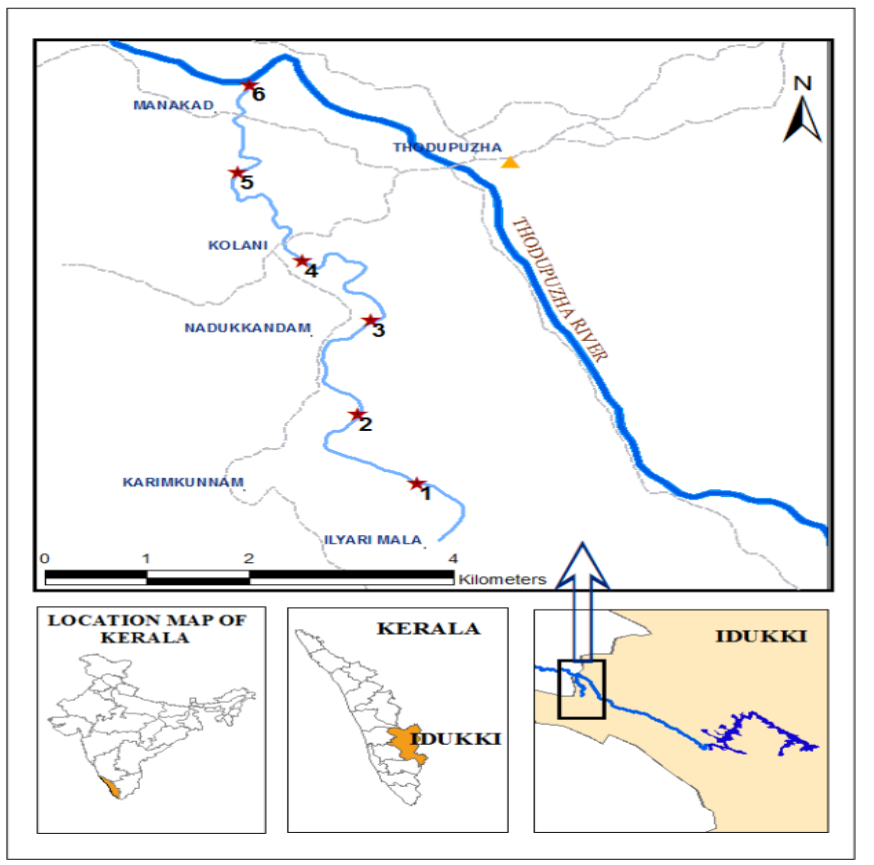

Fig.1.Location map of study area (hill- Stream of Thodupuzha River)

The present study is an investigation of the occurrence of filamentous algae in a hill stream in Kerala, India. The geographic location is $11^{\circ} 37^{\prime} 0^{\prime \prime} \mathrm{N} 76^{\circ} 13^{\prime} 0^{\prime \prime} \mathrm{E}$. The stream under investigation is a seasonal flow 
originating from the hills of Iliyari Mala of Idukki district, Kerala, India, and flows six kilometers downstream to join Thodupuzha river at Manakad (Fig.1). The lower reach of this stream gets cut off as a pond in summer when the upstream flow ceases, and the pond develops a floating scum of filamentous algae. It is this observation that led to this investigation to discover the diversity of filamentous algal species in this seasonal stream, and their probable water quality indication.

\begin{tabular}{|l|c|c|c|c|c|c|}
\hline \multicolumn{1}{|c|}{ Periphyton } & 1 & 2 & 3 & 4 & 5 & 6 \\
\hline Oscillatoria splendida & + & - & + & + & - & - \\
\hline Oscillatoria acuminata & - & + & - & + & - & - \\
\hline Oscillatoria rubescens & + & - & + & + & + & - \\
\hline $\begin{array}{l}\text { Oscillatoria laete- } \\
\text { virens }\end{array}$ & - & - & + & - & - & - \\
\hline Oscillatoria limosa & - & + & - & - & + & - \\
\hline Phormidium tenue & - & - & + & + & - & - \\
\hline Lyngbya shackletoni & - & - & - & + & + & - \\
\hline Nostoc commune & - & - & + & + & - & - \\
\hline Scytonema cinccinatum & - & - & - & + & - & - \\
\hline Oedogonium sp. & + & + & - & - & - & - \\
\hline Spirogyra sp. & - & + & + & + & - & + \\
\hline Zygnema sp. & + & + & - & - & - & - \\
\hline Ecballocystis sp. & + & + & - & - & + \\
\hline
\end{tabular}

\section{Collection Of Sample}

Algal samples were collected at six locations, every kilometer of the stretch of the stream from its origin to the point where it meets the Thodupuzha river during the period February to August 2009. Samples were collected by scraping pebbles, rocks and submerged vegetation, and brought to the laboratory immediately. The samples were studied fresh as far as possible and digital images of the algae were taken. Identification of taxa was restricted to the true filaments of green and blue-green algae as they were the abundant growth in the stream. The taxa were identified based on monographs (Desikachary, 1959[20]; Prescott, 1964[21]; Anand, 1989[22]; Guiry \& Guiry, 2011[23]).Table 1. Periphyton species data at six sampling locations of the stream. presence (+), absence(-)

\section{Results}

Thirteen species of filamentous algae were recorded in the present study (Fig.2). Among these Cyanobacteria were represented by five genera, Chlorophyta were represented by two genera, and Charophyta were represented by two genera. The occurrence of these across the river in the sampling location is given in Table 1. Spirogyra sp. was the most widely distributed followed by Oscillatoria rubescens. The genus Oscillatoria was represented by five species. The bloom formation downstream was that of Spirogyra sp. It formed wide spread scum in the nearly stagnant region of the stream which got cut off as a pond during the summer months of April and May. The bloom was washed off by the monsoon rains in June-July when stream was in flood with turbid water and poor algal growth. The morpho-taxonomic description of the taxa is given below.

\subsection{Oscillatoria splendida Grev.ex Gomont (Fig. 2A)}

(Desikachary, 1959, p. 234, Pl. 37, Fig. 7 \& 8)

Thallus blue green; trichome straight or curved, not constricted at the cross walls, at the end gradually attenuated, 2-3 $\mu$ broad; cells 2-3 times longer than broad rarely quadrate, 3-8 $\mu$ long; ends more or less bent; end cells capitate; nearly rounded.

\subsection{Oscillatoria acuminata Gomont (Fig. 2B)}

(Desikachary, 1959, p. 240, Pl. 38, Fig.7)

Thallus blue-green; trichome more or less straight, not constricted at cross-walls, $4-5 \mu$ broad, at the ends briefly tapering, sharply pointed, bent; cells longer than broad, 6-8 $\mu$ long, sometimes granulated at the cross-walls. 


\subsection{Oscillatoria rubescens DC ex Gomont (Fig. 2C)}

(Desikachary, 1959, p. 235 Pl. 42, Fig.12)

Trichome straight, at the ends gradually attenuated, $6-8 \mu$ broad, not constricted at the cross walls, cells $1 / 2^{-1} / 3$ as long as broad, $3-4 \mu$ long, often granulated at the septa, with gas vacuoles; end cells capitate.

\subsection{Oscillatoria laete-virens (crouan) Gomont (Fig. 2D)}

(Desikachary, 1959, p. 213 Pl. 39, Fig. 2 \& 3)

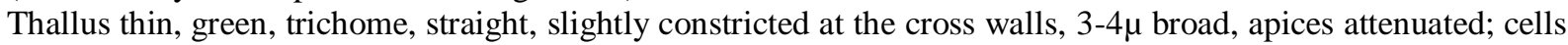
nearly long as broad, $2-4 \mu$ long.

\subsection{Oscillatoria limosa Ag. ex Gomont (Fig. 2E)}

(Desikachary, 1959, p. 206, Pl. 42, Fig.11)

Thallus dark blue green, trichome more or less straight, not constricted at the cross walls, $11-12 \mu$ broad, cross walls frequently granulated; cells $1 / 3^{-1} / 6$ as long as broad, $2-4 \mu$ long; end cells flatly rounded with slightly thickened membrane.

\subsection{Phormidium tenue (Menegh.) Gomont (Fig. 2F)}

(Desikachary, 1959, p. 259, Pl. 43, Fig. 13-15 \& Pl. 44, Fig. 7-9)

Thallus pale blue-green, thin, membraneous, trichome straight, slightly constricted at cross- walls, attenuated at the ends, cells 2-3 times longer than broad, 3-5 $\mu$ long, 1-2 $\mu$ broad; sheath thin.

\subsection{Lyngbya shackletoni W. et G. S. West (Fig. 2G)}

(Desikachary, 1959, p. 296, Pl. 53, Fig. 13)

Filaments nearly straight, $12-12.5 \mu$ broad; sheath firm, colourless, distinctly lamellated; trichome not attenuated at the ends, 8-9 $\mu$ broad; not constructed at cross- walls, cells 2-2.5 $\mu$ long, pale blue-green; end cells conical nearly as long as broad.

3.8. Nostoc commune Vaucher ex Born. et Flah. (Fig. 2H)

(Desikachary, 1959, p. 387, Pl. 68, Fig. 3)

Thallus firm, gelatinous, blue green; sheath mostly distinct only at the periphery, trichome 4-5 $\mu$ broad, cells short barrel-shaped to nearly spherical, heterocysts nearly spherical, 6-7 $\mu$ broad.

\subsection{Scytonema cincinnatum Thuret ex Born.et Flah. (Fig. 2I)}

(Desikachary, 1959, p. 453, Pl. 93, Fig.1)

Thallus brownish green; filaments $16-26 \mu$ broad; false branches mostly germinate; sheath firm, brownish; trichome $14-17 \mu$ broad, distinctly at cross-walls, cells $1 / 3$ as short as broad; heterocysts depressed or quadrate, short cylindrical.

\subsection{Oedogonium Link ex Hirn, 1990 (Fig. 2J)}

(http://www.algaebase.org)

Unbranched uniseriate filaments, occasionally free-floating. Vegetative cells generally uniform in size and shape; usually cylindrical, uninucleate, cap cells present, $21-28 \mu$ long, 16-18 $\mu$ broad, highly vacuolated, and with a large reticulate, parietal chloroplast containing many pyrenoids.

\subsection{Spirogyra Link, 1820 (Fig. 2K)}

(http://www.algaebase.org)

Thalli comprised of unbranched uniseriate filaments, cylindrical cells, $18-22 \mu$ broad; length eqaual to or several times width; chloroplast two, spirally arranged ribbon like with numerous pyrenoids.

\subsection{Zygnema Agardh, 1817 (Fig. 2L)}

(http://www.algaebase.org)

Filaments unbranched with short cylindrical cells, 14-17 $\mu$ broad; two satellite chloroplasts with a prominent central pyrenoid, one on either side of a centrally situated nucleus.

\subsection{Ecballocystis Bohlin, 1897 (Fig. 2M)}

(http://www.algaebase.org)

Microscopic to macroscopic aggregations of cells with one to many celled dendroid to pseudofilamentous colonies attached at base by mucilaginous pad. Cells oval to spindle shaped or cylindrical, $15-20 \mu$ broad, $40-70 \mu$ 
broad, cell walls smooth with lamellated polar thickenings. Cells with single central nucleus; parietal chloroplasts , discoid to band shaped each with single pyrenoid.

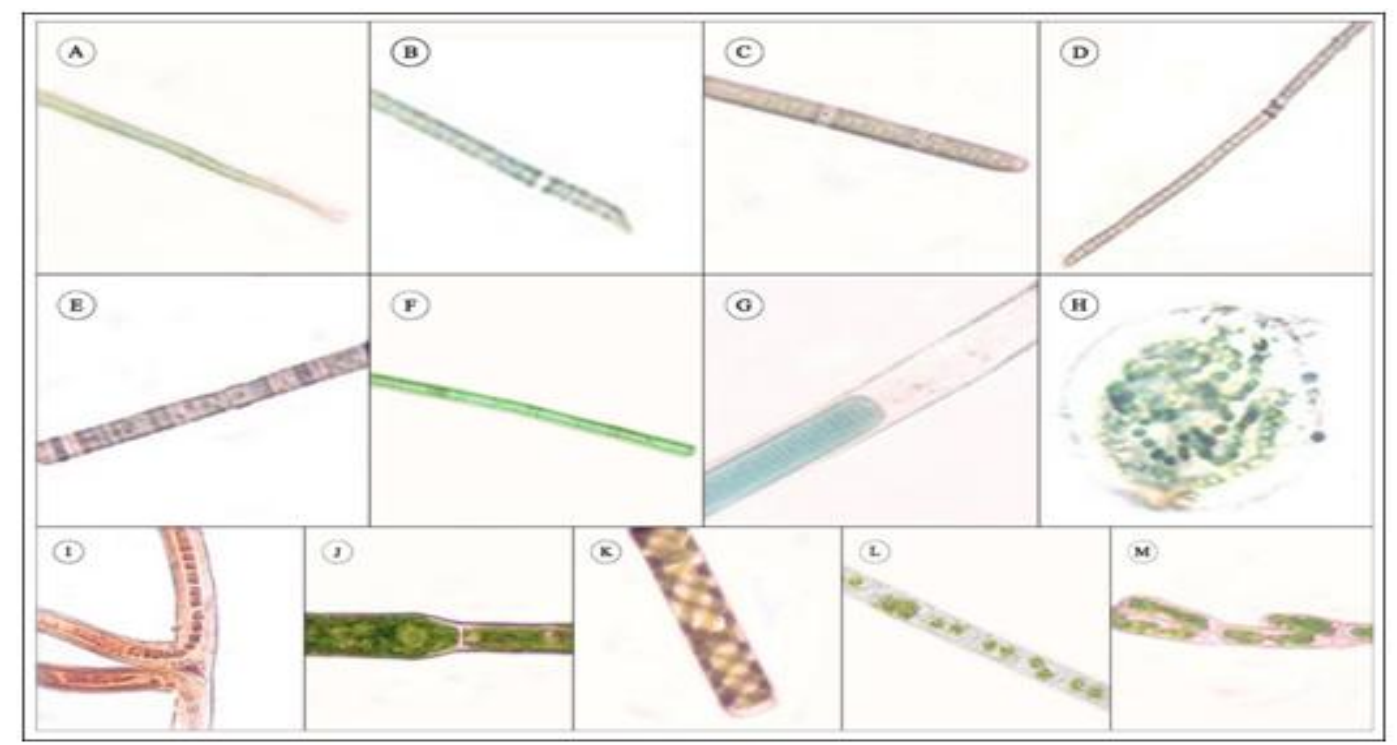

Fig.2. Filamentous algae of study site A. Oscillatoria splendida (1000X) B. Oscillatoria acuminata (400X) C. Oscillatoria rubescens (1000X) D. Oscillatoria laete-virens (400X) E. Oscillatoria limosa (1000X) F. Phormidium tenue (1000X) G. Lyngbya shackletoni (400X) H. Nostoc commune (400X) I. Scytonema cinccinatum (1000X) J. Oedogonium sp. (1000X) K. Spirogyra sp. (400X).L. Zygnema sp. (400X) M. Ecballocystis sp. (400X)

\section{Discussion And Conclusion}

Thirteen species are recorded from this stream in this investigation. All of these have been reported from elsewhere in different rivers and wetlands of Kerala (Anand and Hopper 1987[24]; Arulmurugan et al., 2010[25]; Jose 2008[26]; Jose and Patel 1990[27]; Ushadevi and Panickkar 1994[28]). Oscillatoria has the highest representation of species while Spirogyra is more widespread and form the summer bloom. Spirogyra and other Zygnemataceous taxa have a wide ecological range and they probably prefer soft water (Cambra and Aboal, 1992[29]). According to Palmers Algal genus index(1969) pollution index of Oscillatoria is five and Phormidium is one and the presence of these genera indicates organic pollution[30]. Presence of Anabaena is also an indicator of organic pollution in the water bodies (Jafari and Gunale, 2006[31). Water habitat with high conductivity seems to be suitable for growth and development of Spirogyra (Wongsawad et al., 2012[32]). The observation of bloom of Spirogyra in the stagnant region of the hill stream is indicative of high dissolved load in the stream and that of Oscillatoria especially points to organic load in the system. This may be strongly correlated with human inhabitation, land use and disturbance in the uplands of Kerala such that even a hill stream is polluted. It may be concluded that many such small habitats considered pristine are left unexplored, and it may be necessary to document these ecosystems of local habitats for their conservation.

\section{Acknowledgement}

Authors are thankful to the Cochin University of Science and Technology, Kochi, Kerala, India, for providing the research support and facilities. The first author acknowledges the award of the University fellowship.

\section{References}

[1] R.J.Stevenson, Algal ecology: Freshwater benthic ecosystem ( Academic press.1996).

[2] B.J.F. Biggs, and R.A.Smith, Taxonomic richness of stream benthic algae: Effects of flood disturbance and nutrients, Limnol. Oceanogr., 47(4), 2002, 1175-1186.

[3] G. Janauer, and Dokulil, Biological monitoring of Rivers (John Wiley and Sons, Ltd, 2006).

[4] F.D. J.R. Shields, S.S. Knight and J.M. Stofleth, Stream bed organic carbon and biotic integrity, Aquatic Conservation: Marine And Freshwater Ecosystems, 18, 2008, 761-779

[5] M.Munn, J.Frey, and A. Tesoriero, The Influence of Nutrients and Physical Habitat in Regulating Algal Biomass in Agricultural Streams, Environmental Management, 45(3), 2010,603-615.

[6] R.G. Wetzel, Limnology (Academic Press; San Diego, CA, USA, 2001).

[7] G. Ziglio, M. Siligardi and G. Flaim, Biological monitoring of rivers; Applications and Perspectives (John Wiley and Sons, England. 2006). 
[8] D.M. Denicola, E.D. Eyto, A. Wemaere and K. Irvine. Using epilithic algal communities to assess trophic status in Irish lakes, Journal of Phycology, 40, 2004, 481-495.

[9] M.J. Wargo, and J. R. Holt, Determination of stream reaches in a ridge and valley creek using diatom periphyton communities. Journal of Freshwater Ecology, 13, 2004, 447-456.

[10] A. I. Baba, A. H. Sofi, S. U. Bhat, and A. K. Pandit. Periphytic Algae of River Sindh in the Sonamarg Area of Kashmir Valley, Journal of Phytology, 3(6), 2011, 01-12

[11] L.Cascallar, P. Mastranduonm, P. Mosto, M. Rheinfeld, J.Santiago, C.Tsoukalis and S. Wallace, Periphytic algae Bioindicators of Nitrogen inputs in Lakes, Journal of Phycology 39,2003,7-8.

[12] A. Giorgi, and L. Malacalza, Effect of an industrial discharge on water quality and periphyton structure in a Pampeam stream, Environmental Monitoring and Assessment, 75, 2002,107-119.

[13] B. J. F. Biggs, Eutrophication of streams and rivers: dissolved nutrient-chlorophyll relationships for benthic algae, Journal of the North American Benthological Society, 19,2000,17-31.

[14] O. Dangles, and F. Guerold, Acidification on trophic structure of macro invertebrate communities, Internet Rev. Hydrobiolo. ,84(3), 1999, 287-297.

[15] N .Abdel-Raouf, A.A. Al-Homaidan, and I.B.M. Ibraheem , Review-Microalgae and wastewater treatment, Saudi Journal of Biological Sciences , 19 , 2012,257-275

[16] A.J. Marinelarena, and H.D.D Giorgi, Nitrogen and Phosphorus Removal by Periphyton from Agricultural Wastes in Artificial Streams, Journal of Freshwater Ecology,16(3) 2001,347-353.

[17] L. Christenson, and R. Sims, Production and harvesting of microalgae for wastewater treatment, biofuels, and bioproducts, Biotechnology Advances, 29,2011,686-702.

[18] S.K. Khanal, R.Y. Surampalli, T.C. Zhang, B.P. Lamsal, R.D. Tyagi, and C.M. Kao, Bioenergy and Biofuel from Biowastes and Biomass ( Institute of the American Society of Civil Engineers, Virginia. 2010).

[19] G. Markou, and D. Georgakakis, Cultivation of filamentous cyanobacteria (blue-green algae) in agro-industrial wastes and wastewaters: A review, Applied Energy,88(10), 2011.

[20] T.V. Desikachary, Cyanophyta (I.C.A.R., New Delhi, 1959).

[21] G.W.Prescott, The fresh water algae (W.M.C. Brown Co, Publ. Dubuque, 1964).

[22] N.Anand, Hand book of blue-green algae ( Bishen Singh Mahendra Pal Singh, 23-A, Connaught Place, Dehra Dun, India, 1989).

[23] M.D. Guiry, G.M. Guiry, Algae Base. World-wide electronic publication, National University of Ireland, Galway, 2011. http://www.algaebase.org.

[24] N. Anand, R.S.S. Hopper, Blue green algae from rice fields in Kerala state, India. Hydrobiologia , 144, 1987,226-240.

[25] N. Anand, R.S.S. Hopper, Blue green algae from rice fields in Kerala state, India. Hydrobiologia , 144, 1987,226-240.

[26] J.Jose, An Investigation on the fresh water flora of Idukki district, doctoral diss., M.G. University Kottayam, Kerala, India, 2008.

[27] L. Jose, and R.J. Patel, Ecballocystis ramose.f.minor, Bourrelly et Coute, a rare green algae from India, Cryptogamic Algo.11, 1990,305-308

[28] K. Ushadevi, and M.V.N. Panicker, Species of the genus spirogyra from kerala india, Bibliotheca Phycologica 1994,1-124.

[29] J. Cambra, and M. Aboa1, Filamentous Green Algae Of Spain: Distribution And Ecolog, Lininetica, 8(2), 1992, 13-220.

[30] C.M. Palmer, A composite rating of algae tolerating organic pollution. Journal of Phycology, 5, 1969, 78-82.

[31] N. Jafari, and V R. Gunale, Hydrobiological Study of Algae of an Urban Freshwater River, J. Appl. Sci. Environ. Mgt. ,10 (2), 2006, $153-158$

[32] Wongsawad, P., Peerapornpisal,Y., Saenphet, A. And Lamyong,S. Variation and ecological relevance of green algae, Spirogyra sp.in Northern Thailand using topology of light and scanning electron miocroscope. Journal of the microscopy society of Thailand, 5, $2012,1-4$. 